\title{
The Effectiveness of Core Strength Training to Improve Functional Mobility and Balance in Geriatric Population: A Literature Review
}

ISSN: 2576-8875

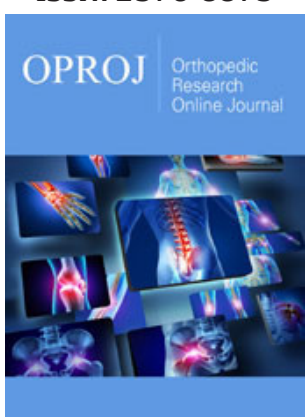

*Corresponding author: Nithya Narayanan Kutty, Associate Professor, Department of Physiotherapy, Cooperative Institute of Health Sciences, India

Submission: 嘀 September 20, 2021

Published: 此 September 28, 2021

Volume 9 - Issue 1

How to cite this article: Manjusha $\mathrm{K}$ Nithya Narayanan Kutty, Shilpa Chandran. The Effectiveness of Core Strength Training to Improve Functional Mobility and Balance in Geriatric Population: A Literature Review. Ortho Res Online J. 9(1). OPROJ. 000701.2021.

DOI: 10.31031/OPROJ.2021.09.000701

Copyright@: Nithya Narayanan Kutty, This article is distributed under the terms of the Creative Commons Attribution 4.0 International License, which permits unrestricted use and redistribution provided that the original author and source are credited.

\section{Manjusha $\mathbf{K}^{1}$, Nithya Narayanan Kutty ${ }^{2 *}$ and Shilpa Chandran ${ }^{3}$}

${ }^{1}$ Post Graduate Student MPT, Cooperative Institute of Health Sciences, India

${ }^{2}$ Associate Professor, Department of Physiotherapy, Cooperative Institute of Health Sciences, India

${ }^{3}$ Assistant Professor, Department of Physiotherapy, Cooperative Institute of Health Sciences, India

\begin{abstract}
Introduction: Core provides proximal stability for distal mobility. Core strength training has a vital role in the improvement of functional Mobility and balance in geriatric Population.

Objective: To establish or review existing studies evaluating the effectiveness of core strength training to improve functional mobility and dynamic balance in geriatric population.

Design: Review of Literature.

Methodology: Various articles from following databases like PubMed, Google scholar, science Direct, research gate Retrieved through a search by using keywords, core strength training, functional mobility, balance, geriatric Population. Total 20 articles were included in the study and based on their findings a review was made.
\end{abstract}

Conclusion: The present literature review concludes that core strength training is beneficial to improve functional mobility and balance in geriatric population.

Keywords: Core strength training; Functional mobility; Balance; Geriatric population

\section{Introduction}

Core Stability (CS) was introduced for the first time in 1990s by Hodges and Richardson during studying the timing of trunk muscles in patients with chronic low back pain. Core strengthening has become a major trend in rehabilitation. Core stability training targets the muscles deep within the abdomen which connect to the spine, pelvis and shoulders, to assist in the maintenance of good posture and provide the foundation for all arm and leg movements [1].

"Core," is composed of the lumbar vertebrae, the pelvis, the hip joints, and the active and passive structures that either produce or restrict movement of this Segment. Core stability can be defined as the ability of the lumbopelvic-hip complex to prevent buckling of the vertebral column and return it to equilibrium following perturbation [2].

Functional Mobility is the most studied and most relevant physical ability affecting quality of life with strong prognostic value for disability and survival. Natural selection has built the "engine" of mobility with great robustness, redundancy, and functional reserve. Efficient patterns of mobility can be acquired during development even by children affected by severe impairments [3]. On average, the rate of decline in walking speed and other measures of lower extremity performance accelerates over the seventh decade of life, starting sometime between the ages of 60-70 years, with an extremely heterogeneous time course across. loss of mobility occurs when the ability to compensate for the cumulative effects of impairments is exhausted and normal daily life becomes a challenge. Slower walking speed (most commonly assessed using usual walking speed achieved during a timed walk test over a short distance) and other 
multisystem performance measures of physical function (such as the time taken to rise from a chair and sit down several times, or tests of balance) are consistently associated with poorer well-being and quality of life in old age, track overall health status, and predict adverse health outcomes, including rising multi morbidity, health care resource utilization, disability in activities of daily living, nursing home admission, and earlier mortality [3].

Balance is considered a key component in many activities of daily living, from simple activities such as quiet standing, to more complex activities such as walking while talking or while changing directions. These different tasks require different components of balance ability, which are usually divided into two types of balance: static and dynamic. Static balance is defined as the ability to maintain an upright posture and to keep the line of gravity within the limits of the base of support (i.e., quiet standing). Dynamic balance is defined as the ability to maintain stability during weight shifting often while changing the base of support. The abdominals serve as a particularly vital component of the core. The transversus abdominis that run horizontal (except for the most inferior fibers, which run parallel to the internal oblique muscle), creating a belt around the abdomen. "Hollowing in" of the abdomen creates isolate activation of the transversus abdominis. The transverses abdominis and multifidi have been shown to contract $30 \mathrm{~ms}$ before movement of the shoulder and $110 \mathrm{~ms}$ before movement of the leg in healthy people, theoretically to stabilize the lumbar spine [4].

In 2012 Granacher et al. [5] and colleagues conducted first study that investigated the impact of core instability strength training on measures of trunk muscle strength, spinal and functional mobility as well as on balance in healthy and physically active seniors. Core strength training can reduce the risk of falls by challenging the nervous system to maintain balance and movement coordination. In a 2013 mega-analysis published in "Sports Medicine," researchers concluded that core strength training can increase strength by an average of 30 percent and balance and functional performance by 23 percent among seniors [5].

The core strengthening exercise was proven that it was effective in improving balance ability of elderly and in preventing getting a bruise from a fall. Aging leads to loss of balance and stability hence Core strengthening program help elderly to independence in life activity \& also improve the balance and quality of life [6].

\section{Objective}

To establish or review existing studies evaluating the effectiveness of core strength training to improve functional mobility and dynamic balance in geriatric population.

\section{Methodology}

\section{Data bases searched}

Pubmed, Google Scholar, Research Gate

\section{Queries used}

Core strength training, functional mobility, balance, geriatric population

To review the literatures that describes and evaluate the effectiveness of core muscle strengthening program to improve functional mobility and balance in geriatric population. Relevant articles in English were received through search of Pub Med, Google scholar, Research gate. Total 20 articles were taken and studied out of which 11 experimental studies, 3 comparative study, 2 cross sectional study, 2 review literature, 1 uncontrolled study and 1 longitudinal study were included. The inclusion criteria were geriatric population, the effect core strength training given studied and published from 2000 to present, studies published in English language, recent research. Exclusion criteria were studies published before 2000, studies conducted among younger adults, athletes. The purpose of the review was to gain an understanding about the benefits of core strength training in geriatric population in the area of functional mobility and balance to overcome repeated events of falls. The following key words are used in combinations: core strength training, functional mobility, balance, geriatric population.

\section{Result}

Total 20 articles were taken and studied. The review study is tabulated in Table 1A. About author, title of the study and final conclusion of the study were described below in the Table 1 ; [7-24].

Table 1

\begin{tabular}{|c|c|c|}
\hline Author & Title & Conclusion \\
\hline $\begin{array}{c}\text { Ketki P et al. } \\
\text { comparative study [7] }\end{array}$ & $\begin{array}{l}\text { Effect of Core Stabilization Exercises on Balance } \\
\text { Performance in Older Adults }\end{array}$ & $\begin{array}{l}\text { Core stabilization exercises had significant } \\
\text { improvement on balance. }\end{array}$ \\
\hline $\begin{array}{l}\text { Hassan S et al. } \\
\text { Experimental study [8] }\end{array}$ & $\begin{array}{c}\text { The Effects of Core Stability Exercises on Balance and } \\
\text { Walking in Elderly Fallers with Mild Cognitive Impairment: A } \\
\text { Randomized Control Trial }\end{array}$ & $\begin{array}{l}\text { It seems that strengthening the muscles in the } \\
\text { central area of the body leads to maintaining balance in } \\
\text { the elderly during daily activities }\end{array}$ \\
\hline $\begin{array}{l}\text { Marceli M et al. } \\
\text { Cross sectional study [9] }\end{array}$ & $\begin{array}{l}\text { Strength and Endurance Influence on the Trunk Muscle in } \\
\text { the Functional Performance of Elderly Women. }\end{array}$ & $\begin{array}{l}\text { There is a great participation of the trunk muscles, } \\
\text { mainly of the endurance, for activities that involve } \\
\text { everyday actions. }\end{array}$ \\
\hline $\begin{array}{l}\text { Agris L et al. } \\
\text { Literature review [10] }\end{array}$ & $\begin{array}{c}\text { A systemic review: a comparison of traditional with motor } \\
\text { learning core stability training approaches regarding the effect } \\
\text { on lower and upper extremity use, balance and functional } \\
\text { performance in older adults }\end{array}$ & $\begin{array}{c}\text {. Currently available literature does not present a } \\
\text { wealth of information about the best strategy for core } \\
\text { stability training in seniors. }\end{array}$ \\
\hline $\begin{array}{l}\text { Higuchi et al. } \\
\text { Uncontrolled study [11] }\end{array}$ & $\begin{array}{l}\text { Sitting trunk exercise for older adult to improve balance and } \\
\text { mobility:a pilot study. }\end{array}$ & $\begin{array}{l}\text { Among community- dwelling older adults, trunk } \\
\text { exercises in the sitting position might be effective in } \\
\text { improving trunk muscle, balance, and mobility }\end{array}$ \\
\hline
\end{tabular}




\begin{tabular}{|c|c|c|}
\hline $\begin{array}{l}\text { Garima et al. } \\
\text { Comparative study [12] }\end{array}$ & $\begin{array}{l}\text { Effect of core stability exercises using swiss ball on balance } \\
\text { performance and quality of life in elderly }\end{array}$ & $\begin{array}{l}\text { core stability exercises using Swiss ball are more } \\
\text { effective than floor exercises in elderly for improving } \\
\text { balance performance. }\end{array}$ \\
\hline $\begin{array}{l}\text { Bastani M et al. } \\
\text { Experimental study [13] }\end{array}$ & $\begin{array}{c}\text { The Effect of Selected Core Stability Exercises on Balance } \\
\text { and Muscle Endurance in the Elderly Patients undergoing } \\
\text { heamodialysis. }\end{array}$ & $\begin{array}{l}\text { core stability exercises as a safe and functional } \\
\text { strategy to improve balance and muscle endurance in } \\
\text { patients undergoing hemodialysis, which may result in } \\
\text { increased independence of action and reduced risk of } \\
\text { falling due to loss of balance. }\end{array}$ \\
\hline $\begin{array}{l}\text { Sannicandro et al. } \\
\text { Experimental study [14] }\end{array}$ & $\begin{array}{c}\text { Effects of a Core Stability Program on Strength and Balance } \\
\text { Skills in Senior Over } 65\end{array}$ & $\begin{array}{l}\text { the core stability exercises can be introduced into } \\
\text { senior fall prevention programs and to get positive } \\
\text { transfer on strength and balance ability in }>65 \text { aged }\end{array}$ \\
\hline $\begin{array}{l}\text { Choi, su- Hee et al. } \\
\text { Experimental study [15] }\end{array}$ & $\begin{array}{l}\text { The Effects of Trunk Stabilization Exercise Using Swiss Ball } \\
\text { and Core Stabilization Exercise on Balance and Gait in Elderly } \\
\text { Women }\end{array}$ & $\begin{array}{l}\text { These finding indicate that trunk stabilization } \\
\text { exercise using swiss ball could improve balance and } \\
\text { gait in elderly women. }\end{array}$ \\
\hline $\begin{array}{l}\text { Gui-bin Song et al. } \\
\text { Experimental study [16] }\end{array}$ & $\begin{array}{l}\text { Effects of Neck and Trunk Stabilization Exercise on Balance } \\
\text { in Older Adults }\end{array}$ & $\begin{array}{l}\text { : According to the results of this study, both } \\
\text { exercises effectively improved static and dynamic } \\
\text { balance ability. However, the neck and trunk } \\
\text { stabilization exercise is more efficient for increasing the } \\
\text { balance ability of older adults. }\end{array}$ \\
\hline $\begin{array}{c}\text { Markovic et al. } \\
\text { Comparative study [17] }\end{array}$ & $\begin{array}{l}\text { Effects of feedback-based balance and core resistance } \\
\text { training vs. Pilates training on balance and muscle function in } \\
\text { older women: a randomized controlled trial }\end{array}$ & $\begin{array}{l}\text { Feedback-based balance and core resistance } \\
\text { training proved to be more effective in improving } \\
\text { single- and dual- task balance ability, trunk muscle } \\
\text { strength, leg power, and body composition of healthy } \\
\text { older women than the traditional Pilates training. }\end{array}$ \\
\hline $\begin{array}{l}\text { Nishad A et al. } \\
\text { Experimental study [18] }\end{array}$ & $\begin{array}{l}\text { Randomized controlled trial of core strengthening in older } \\
\text { adults; effect on functional mobility }\end{array}$ & $\begin{array}{c}\text { core strength training could be successfully utilized } \\
\text { in senior independent living communities to improve } \\
\text { balance and mobility and potential to reduce risk of } \\
\text { falls. }\end{array}$ \\
\hline $\begin{array}{c}\text { Zhumei shi et al. } \\
\text { Experimental study [19] }\end{array}$ & Effect of core stability training on balance in elderly women. & $\begin{array}{l}\text { core stability training more beneficial than walking } \\
\text { exercise in improving balance in elderly women. }\end{array}$ \\
\hline $\begin{array}{l}\text { Kahle N et al. } \\
\text { Experimental study [20] }\end{array}$ & $\begin{array}{l}\text { core muscle strengthening's improvement of balance } \\
\text { performance in community dwelling older adults a pilot study }\end{array}$ & $\begin{array}{l}\text { core strengthening should be a Part of a } \\
\text { comprehensive balance training programme for older } \\
\text { adults }\end{array}$ \\
\hline $\begin{array}{c}\text { Arora et al. } \\
\text { Longitudinal study [6] }\end{array}$ & $\begin{array}{l}\text { Effect of core muscle strengthening on balance and quality of } \\
\text { life in geriatric patients }\end{array}$ & $\begin{array}{l}\text { core muscle strengthening is effective in improving } \\
\text { balance and quality of life in geriatric subjects. }\end{array}$ \\
\hline $\begin{array}{l}\text { Granacher et al. } \\
\text { Literature review [5] }\end{array}$ & $\begin{array}{l}\text { The importance of trunk muscle strength for balance, } \\
\text { functional performance, and fall prevention in seniors: a } \\
\text { systematic review. }\end{array}$ & $\begin{array}{l}\text { Core strength training and/or PET can be used as } \\
\text { an adjunct or even alternative to traditional balance } \\
\text { and/or resistance training programs for old adults. }\end{array}$ \\
\hline $\begin{array}{c}\text { Granacher et al. } \\
\text { Experimental study }[21]\end{array}$ & $\begin{array}{l}\text { Effect of core instability strength training on trunk muscle } \\
\text { strength, spinal mobility, dynamic balance and functional } \\
\text { mobility in older adults }\end{array}$ & \\
\hline $\begin{array}{l}\text { Kwonyoung K et al. } \\
\text { Experimental study [22] }\end{array}$ & $\begin{array}{l}\text { Effect of core strengthening exercise programme on } \\
\text { symmetric double limb support and balance ability for the } \\
\text { elderly. }\end{array}$ & $\begin{array}{l}\text { This study sought to apply the core strengthening } \\
\text { exercise to improve the balance ability for elderly in } \\
\text { a bid to study an effective exercise method to prevent } \\
\text { getting a bruise from a fall. }\end{array}$ \\
\hline $\begin{array}{l}\text { Pradeep S et al. } \\
\text { Cross sectional study } \\
\text { [23] }\end{array}$ & $\begin{array}{l}\text { Trunk muscle attributes are associated with balance and } \\
\text { mobility in older adults: a pilot study }\end{array}$ & $\begin{array}{l}\text { Trunk endurance and strength can be safely } \\
\text { measured in mobility limited older adults and are } \\
\text { associated with both balance and mobility performance. } \\
\text { Trunk endurance and strength are physiologic attribute } \\
\text { worthy of targeting in rehabilitative care of mobility } \\
\text { limited older adults. }\end{array}$ \\
\hline $\begin{array}{l}\text { Jerrold s et al. } \\
\text { Experimental study }[24]\end{array}$ & Core strengthening and balance in geriatric population & $\begin{array}{l}\text { strengthening of core does aid in functional } \\
\text { abilities }\end{array}$ \\
\hline
\end{tabular}

\section{Discussion}

The present study demonstrates a correlation between core strength training, functional mobility and balance ability in geriatric population. This analysis support and update the finding of previous reviews and identifies that core strength training is beneficial for the improvement of functional mobility and balance in older adult to achieve a good quality of life. The analysis supports the theory of Hodges and Richardson in 1996 according to him transverse abdominis contract before any Limb movement.

The core musculature is also responsible for generating a variety of movement of trunk in many planes of motion before leg movement. The data suggest that Core muscles are the kinetic link that transfers. 
The torques and angular moment between upper and lower extremities during the execution of whole-body movements [25].

Global muscles (Rectus abdominis, external obliques and some parts of the erector spinae) are ideal for creating movement of the trunk and producing torque, because of their large moment arms and long levers as they are attached from the thorax to the pelvis [26]. These muscles are labelled as the prime movers for trunk or hip flexion, extension, and rotation. During whole body movement stability of core associated with Local muscles. [c]Local muscles (Transverses abdominis, multifidus, pelvic floor, diaphragm, and internal obliques are responsible for producing sufficient force for segmental stability of the spine [27]. The coordinated muscle recruitment between the global muscles and the local muscle during functional activities maintains stability of the core spine [28]. Core stabilization exercises helps in improving neuromuscular control, strength, and endurance of the muscles [29]. Core stability training targets the muscles deep within the trunk which are connected to the spine, pelvis and shoulders and it assists in maintaining good posture and provides the foundation for arm and leg movements [30]. Exercises that target core muscles are effective for core stabilization and motor control training and thus are used for maintaining balance. Studies suggested that core muscles play an important role in improving balance and training functional mobility in older adults. Study done by Sure et al. [29] have shown associations between diminished trunk muscle strength, endurance, muscle quality, and poor balance in older adults.

\section{Conclusion}

The present literature review concludes that core strength training is beneficial to improve functional mobility and balance in geriatric population.

\section{References}

1. Akuthota, Ferreira, Moore (2008) 8 Frederickson, John D. Wilson, MSPT, New York, USA.

2. John Willson, Dougherty P, Lloyd IM, McClay Davis (2005) Core stability and its relationship to lower extremity function and injury. Acad Orthop Surg 13(5): 316-325.

3. Ferrucci L, Cooper R, Shardell M, Simonsick EM, Schrack J, et al. (2016) Age-related change in mobility: perspectives from life course epidemiology and geosciences. J Gerontol A Biol Sci Med Sci 71(9): 1184-1194.

4. Venu A, Ferreiro A, Moore T, Fredericson M (2008) Core stability exercise principles. Curr Sports Med Rep 7(1): 39-44.

5. Granacher U, Gollhofer A, Muehlbauer T, Kressig R, Tibor H (2013) the importance of trunk muscle strength for balance, functional performance, and fall prevention in seniors: A systematic review. Sports Medicine 43(7): 627-641.

6. Pooja A, Sujatha Y, Siddiqui N (2013) Effect of core muscle strengthening on balance and quality of life in geriatric patient. Indian Journal of Physiotherapy \& Occupational Therapy 7 (2).

7. Ketki P, Ronika A, Nazneen (2021) Effect of core stabilization exercise on balance performance in older adults. International Journal of Contemporary Medicine 9(1).

8. Hassan S, Shojaedin S, Alijanpour E, Ali Abbasi (2020) The effects of core stability exercises on balance and walking in elderly fallers with mild cognitive impairment: A randomized control trial. Journal of Research in Rehabilitation Sciences 16: 110-117.

9. Marceli M, Marta S, Alan B, Antônio G, José C, et al. (2019) Strength and endurance influence on the trunk muscle in the functional performance of elderly women. International Journal of Sports and Exercise 5(10).

10. Agris L , Ruud H (2019) A systematic review: A comparison of traditional with motor learning core stability training approaches regarding the effect on lower and upper extremities use, balance and functional performance in older adults. comparison of traditional with motor learning core stability training approaches in seniors: A Systematic Review.

11. Y Higuchi, H Matsumoto, Matsubara C, Morimoto N, Ishida R, et al. (2018) Sitting trunk exercise for older adult to improve balance and mobility: A pilot study. Innov Aging 2(Suppl 1): 314.

12. Garima, Deepthi S, Arora B (2018) Effect of core stability exercises using swiss ball on balance performance and quality of life in elderly. International Journal of Multidisciplinary Education and Research 3(1).

13. Bastani M, Ghasemi G, Sadeghi M, Afshon A, Hossien S (2017) The effect of selected core stability exercises on balance and muscle endurance in the elderly patients undergoing haemodialysis. Physical Treatments $7(2): 89-96$

14. Sannicandro I (2017) Effects of a core stability program on strength and balance skills in senior over 65. International Journal of Science and Research, ISSN: 2319-7064.

15. Choi Su-Hee (2012) The effects of trunk stabilization exercise using swiss ball and core stabilization exercise on balance and gait in elderly. Journal of the Korean Society of Physical Medicine 7(1): 49-58.

16. Song G, Eun-Cho Park (2016) Effects of neck and trunk stabilization exercise on balancein older adults. J Kor Phys Ther 28(4): 221-226.

17. Markovic G, Sarabon N, Greblo Z, Krizanic V (2015) Effects of feedbackbased balance and core resistance training vs. Pilates training on balance and muscle function in older women: A randomized-controlled trial. Arch Gerontol Geriatr 61(2): 117-123.

18. Nishad A, Nizae A (2015) Randomized controlled trial of core strength training in older adults: Effects on functional mobility. Scholars Academic Journal of Biosciences 3(1A): 19-25.

19.Zhumei Shi, Junhua Zhou (2014) Effect of core stability training on balance in elderly women. Family Medicine and Community Health 2(4): 48-52.

20. Kahle N, Tevald M (2014) Core muscle strengthening's improvement of balance performance in community-dwelling older adults: A pilot study. Journal of Aging and Physical Activity 22(1): 65-73.

21. Granacher U, Lacroix A, Muehlbauer T, Roettger K, Gollhofer A (2013) Effects of core instability strength training on trunk muscle strength, spinal mobility, dynamic balance and functional mobility in older adults. Gerontology 59(2): 105-113.

22. Kwonyoung K (2021) Effect of core strengthening exercise programs on symmetric double limb support and balance ability for the elderly. Journal of International Academy of Physical Therapy Research 3(1): 378-382.

23. Pradeep S, Kiely D, Suzanne G, Walter R, Jonathan B (2009) Trunk muscle attributes are associated with balance and mobility in older adults: A pilot study. PMR 1(10): 916-924.

24. Jerrold S, Cuneo M, Dial R, Pawley A, Hill J (2005) Core strengthening and balance in the geriatric population. The Journabf Applied Research 5(3): 423.

25. Amira A, Abdallah A, Beltagi A (2014) Effect of core stability exercises on trunk muscle balance in healthy adult individuals. International Journal of Medical, Health, Biomedical, Bioengineering and Pharmaceutical Engineering 8(5):243-248. 
26. Nicole K (2009) The Effects of core stability training on balance testing in young, healthy adults. Thomas, Toledo, USA.

27. O sullivan P (2000) Lumbar segmental instability': Clinical presentation and specific stabilizing exercise management. Manual Therapy 5(11): 2-12.

28. Moon H, Choi K, Kim D, Kim H, Cho Y, et al. (2013) Effects of core stabilization and dynamic core strengthening on patients with chronic low back pain. Ann Rehab Med 37(1): 110-117.
29. Suri P, Kiely D, Leveille S, Frontera W, Bean J (2009) Trunk muscle attributes are associatedwith balance and mobility in older adults: A pilot study. PM R 1(10): 916-924.

30. Kang K, Choi J, Lee S (2012) Effects of core strengthening exercises on symmetrical doublelimb support and balance ability for the older adults. J Int Acad Phy Ther Res 3(1): 345-411.

For possible submissions Click below:

Submit Article 